7-1-2008

\title{
The Human Factor: Globalizing Ethical Standards in Drug Trials through Market Exclusion
}

\author{
Fazal Khan \\ University of Georgia School of Law, fkhan@uga.edu
}

p bepress

\section{Repository Citation}

Fazal Khan, The Human Factor: Globalizing Ethical Standards in Drug Trials through Market Exclusion (2008),

Available at: https://digitalcommons.law.uga.edu/fac_artchop/561

This Article is brought to you for free and open access by the Faculty Scholarship at Digital Commons @ University of Georgia School of Law. It has been accepted for inclusion in Scholarly Works by an authorized administrator of Digital Commons @ University of Georgia School of Law. Please share how you have benefited from this access For more information, please contact tstriepe@uga.edu. 


\title{
THE HUMAN FACTOR: GLOBALIZING ETHICAL STANDARDS IN DRUG TRIALS THROUGH MARKET EXCLUSION
}

\author{
Fazal Khan*
}

\section{INTRODUCTION}

She was only ten years old and suffering from bacterial meningitis, a serious infectious disease that was sweeping through West Africa. ${ }^{1}$ Meningitis attacks the protective membranes covering the brain and spinal cord and can cause serious neurologic damage or even death. ${ }^{2}$ The good news for the girl and her family was that there was an effective treatment for this disease: intravenous (IV) antibiotics. ${ }^{3}$ Further, once they arrived at the clinic in Kano, Nigeria, they met Western doctors in white coats offering free drugs. ${ }^{4}$ However, three days later, the girl died; she had not received proven antibiotic therapy, but only an experimental drug called Trovan. ${ }^{5}$ The girl's family-along with many others-later claimed that, instead of receiving medical care, they were unwittingly participating in a multinational drug company's experimental trial that led to the serious impairment or death of many children. ${ }^{6}$ Why would a drug company do something like this? If data

* Assistant Professor of Law, The University of Georgia School of Law. B.A., University of Chicago; M.D., University of Illinois College of Medicine; J.D., University of Illinois College of Law. I would like to thank those who gave me valuable input in response to my presentation of this paper at the Health Law Scholars Workshop at St. Louis University School of Law. Specifically, I want to thank Professors Tim Greaney, Sandra Johnson, Jesse Goldner, Peter Hammer, Sydney Watson, David Sloss, Rob Schwartz, Lisa Ikemoto, Dianne Hoffman, Elizabeth Pendo, and Kelly Dineen. This paper also benefited from comments received after my presentation at the 2007 South East Association of Law Schools (SEALS) Annual Conference. In particular, I want to thank the insightful comments of Helen Grant.

1. See Joe Stephens, Where Profits and Lives Hang in Balance, WASH. Post, Dec. 17, 2000, at A1. The Washington Post published a six-part series entitled The Body Hunters, which examined the growing phenomenon of international clinical drug testing, highlighting the system's tendency to exploit the poor and uneducated while betraying promises of safety and effectiveness to patients and consumers. This article was the first of the series.

2. See World Health Org., Meningococcal Meningitis, http://www.who.int/mediacentre/factsheets/fs141/en/ (last visited Feb. 12, 2008).

3. See Stephens, supra note 1.

4. See id.

5. Id.

6. Abdullahi v. Pfizer, Inc. (Abdullahi I), No. 01-Civ.-8118, 2002 U.S. Dist. LEXIS 17436, at *1-8 (S.D.N.Y. Sept. 16, 2002). 
from the experiment helped the drug obtain market approval and it became a blockbuster, this company would have over a billion reasons. $^{7}$

Given the tremendous financial reward that a blockbuster therapy might generate, there are strong incentives to move drug research and development to developing countries, which have minimal ethical guidelines and little transparency. ${ }^{8}$ The danger in this race for the prize - or for the bottom-is the exploitation of subaltern populations that have little legal recourse to hold drug companies accountable for the harm that those populations suffer as a result of unethical clinical trials. ${ }^{9}$ In other words, the drug industry is acutely aware that there is a minimal threat of costly civil suits and criminal sanctions for their ethical violations in impoverished countries. The result is that it has become an industry practice to relax international ethical norms for drug trials in developing countries. ${ }^{10}$ This does not mean that drug companies are inherently unethical institutions-these corporations are composed of persons who are simply being human and responding to structural incentives. Additionally, the statistics derived from these clinical trials represent actual human individuals, who are also responding to the structural incentives that exist for them: a promise of healthcare only if they submit to risky experiments.

This Article is part one of a two-part series that seeks to deter unethical clinical drug trials in developing nations by preventing unethi-

7. Stephens, supra note 1 (noting Wall Street analysts' projections that Trovan would be a $\$ 1$ billion drug if approved for all of its potential uses).

8. The term "developing countries" is used here to denote countries with relatively low standards of living and undeveloped infrastructures. See U.S. Dep't of State, International Information Programs Glossary, available at http://usinfo.state.gov/products/pubs/trade/glossdi.htm (last visited Feb. 12, 2008). This term has largely replaced the use of "third world" to describe similarly situated nations. See Robert O'Brien \& Marc Williams, Global Political Econ. OMY: Evolution AND DYNAmics 258 (2004).

9. The term "subaltern" is used here in the Gramscian sense to denote marginalized individuals or groups that do not possess agency as a consequence of their social status. See Selections from the Prison Notebooks of Antonio Gramsci 52-55 (Quintin Hoare \& Geoffrey Nowell Smith eds. \& trans., 1971).

10. See David M. Kent et al., Clinical Trials in Sub-Saharan Africa and Established Standards of Care: A Systematic Review of HIV, Tuberculosis, and Malaria Trials, 292 JAMA 237, 239 (2004) (looking at compliance with the Declaration of Helsinki's "best current" therapeutic standard and finding that only $16 \%$ of selected trials met this standard, despite $81 \%$ of the trials reporting oversight by an ethics review board). Abdullahi I presented just one example of this relaxation of ethics. Although the Abdullahi I court took the facts alleged by the plaintiffs in the complaint as true for purposes of the motions before it, see Abdullahi I, 2002 U.S. Dist. LEXIS 17436 , at $* 8$, the alleged facts have been corroborated by independent witnesses in a variety of press accounts and legal journal articles. See, e.g., Sarah Boseley, New Drug 'Illegally Tested on Children': Pfizer Accused of Irregularities During Clinical Trial in Nigeria, The Guardian (London), Jan. 17, 2001, at 19; Stephens, supra note 1. 
cally developed products from gaining market approval." In particular, this Article argues for a combination of soft-law techniques, including more robust and subaltern-centric surveillance of international drug trials, and hard-law rules within the regulatory agencies of the United States and the European Union (EU) that require clinical drug research to adhere to international ethical standards. The intended result would be a stiff economic penalty: exclusion from lucrative markets. This in turn would create a strong ex ante economic incentive for drug companies to ethically conduct drug trials. ${ }^{12}$

First, this Article outlines how the international community's current medical ethics regime has emerged as a reaction to historical ethical abuses. ${ }^{13}$ Next, it addresses how globalization has transformed human drug-testing trials and, in the process, has rendered inadequate the current ethics regime, which does not operate well across international borders into developing nations. ${ }^{14}$ Finally, this Article describes how soft law, which can work effectively across international borders, can be used to effectuate hard-law sanctions, such as blocking market approval within the United States and the EU, to deter unethical practices in clinical drug trials. ${ }^{15}$

\section{Exorcising History's Demons: The Genesis of Current Ethical Norms}

This Part explains how the development of international bioethical guidelines has largely been a narrative of society's reaction to medical and scientific transgressions after the fact. In particular, it describes three of the most prominent statements on bioethics: the Nuremberg

11. The second part of this two-part series proposes stripping pharmaceutical companies' intellectual property rights for drugs that are developed unethically not only to serve as an additional deterrent, but to also address the social cost issue that arises if a medically beneficial drug is excluded from the market.

12. In a sense, this proposal operates almost like the "fruit of the poisonous tree" doctrine from U.S. jurisprudence. This doctrine makes evidence obtained with the help of illegally gathered information inadmissible. See, e.g., Wong Sun v. United States, 371 U.S. 471, 484-88 (1963). The logic of this doctrine is that if the source of the evidence (the "tree") is tainted, then anything gained from the tree (the "fruit") is likewise tainted. See id. To remove the incentive for illegal searches and to ultimately deter such behavior, the tainted information is generally inadmissible in court. See id.

13. See infra notes $16-90$ and accompanying text.

14. See infra notes 91-169 and accompanying text: See also Abdullahi v. Pfizer, Inc. (Abdullahi III), No. 01-Civ.-8118, 2005 U.S. Dist. LEXIS 16126 (S.D.N.Y. Aug. 9, 2005) (dismissing class-action plaintiffs' case for lack of subject matter jurisdiction under the Alien Tort Statute and forum non conveniens); Kent, supra note 10.

15. See infra notes $170-238$ and accompanying text. 
Code, ${ }^{16}$ the World Medical Association's Declaration of Helsinki, ${ }^{17}$ and the Belmont Report. ${ }^{18}$ Finally, this Part explains how these ethical standards are applied to human clinical trials by drug regulatory agencies. ${ }^{19}$

\section{A. The Nuremberg Code: Reacting to Nazi Horrors}

Modern bioethics, in the form of the Nuremberg Code (the "Code"), arose as a strong reaction to the horrific Nazi medical experiments of World War II. The sheer inhumanity of these experiments became public record immediately after World War II during the $\mathrm{Nu}$ remberg Trials. ${ }^{20}$ These experiments were invariably performed on prisoners in concentration camps and not on volunteers affiliated with the German military or the Nazi party. ${ }^{21}$ The purported rationales for these experiments ranged from advancing medical and military knowledge to proving pseudoscientific racist theories. ${ }^{22}$ In one of the "military" experiments, Dr. Sigmund Rascher placed prisoners in a decompression chamber to determine the best means of rescuing pilots who had to abandon their planes at high altitudes, where there was little oxygen and low atmospheric pressure. ${ }^{23}$ Rascher would often dissect victims' brains-some while they were still alive-"to show that high altitude sickness [was caused by] the formation of tiny air bubbles in the blood vessels [in a particular part] of the brain." 24 In a trial to discover how long downed German pilots could survive in

16. See infra notes $20-31$ and accompanying text.

17. See infra notes $32-37$ and accompanying text.

18. See infra notes $38-67$ and accompanying text.

19. See infra notes $68-90$ and accompanying text.

20. Sharona Hoffman, Beneficial and Unusual Punishment: An Argument in Support of Prisoner Participation in Clinical Trials, 33 IND. L. REv. 475, 483 (2000). The Japanese military also tested biowarfare agents on unwitting Chinese subjects in occupied Manchuria by spraying infectious diseases over populated areas and infecting well-water and other foodstuffs, and then examining the rate of disease and effect on the Chinese population. See id. Unlike the Nuremberg Trials, no international war crimes tribunal was held for these Japanese experiments, because the U.S. military was interested in the results for its own biowarfare program and granted the Japanese scientists immunity in exchange for shared research findings. See Ralph Blumenthal with Judith Miller, Japan Rebuffs Requests for Information About Its Germ-Warfare Atrocities, N.Y. Times, Mar. 4, 1999, at A12.

21. See Hoffman, supra note 20 , at 483.

22. U.S. Holocaust Memorial Museum, Nazi Medical Experiments, Holocaust EnCYClopeDIA, available at http://www.ushmm.org/wlc/article.php?lang=EN\&ModuleId=10005168 (last visited Feb. 12, 2008).

23. Transcript of Medical Trial at 207-09, Nuremberg War Trials (Dec. 11, 1946), available at http://nuremberg.law.harvard.edu/NurTranscript/TranscriptPages (follow links to specific page numbers).

24. Peter Tyson, The Experiments, available at http://www.pbs.org/wgbh/nova/holocaust/experiside.html (last visited Feb. 12, 2008). 
the frigid North Sea, Rascher immersed prisoners in ice water tanks for varying amounts of time and then attempted to revive them using different warming methods. ${ }^{25}$ Naturally, many of these prisoners died of hypothermia. Other Nazi trials subjected prisoners to the effects of sea water, toxic gas, bone transplantation, sterilization, and various infectious diseases. ${ }^{26}$ At the conclusion of the Nuremberg trials, twenty-three Nazi doctors were convicted of committing "war crimes and crimes against humanity," and seven of those doctors were executed for their actions. ${ }^{27}$.

The lasting legacy of this tribunal is the Code, which, for the first time, set out an international consensus statement of what constituted ethical treatment of humans in clinical trials. ${ }^{28}$ The Code contains ten points that elucidate the circumstances where human medical experimentation is ethical and permissible. ${ }^{29}$ The first line of the Code

25. $I d$.

26. $I d$.

27. Hoffman, supra note 20 , at 483.

28. See Robert J. Levine, New International Ethical Guidelines for Research Involving Human Subjects, 119 Annals Internal Med. 339 (1993).

29. The ten points of the Code are found as follows:

1. The voluntary consent of the human subject is absolutely essential.

This means that the person involved should have legal capacity to give consent; should be so situated as to be able to exercise free power of choice, without the intervention of any element of force, fraud, deceit, duress, over-reaching, or other ulterior form of constraint or coercion; and should have sufficient knowledge and comprehension of the elements of the subject matter involved as to enable him to make an understanding and enlightened decision. This latter element requires that before the acceptance of an affirmative decision by the experimental subject there should be made known to him the nature, duration, and purpose of the experiment; the method and means by which it is to be conducted; all inconveniences and hazards reasonable to be expected; and the effects upon his health or person which may possibly come from his participation in the experiment.

The duty and responsibility for ascertaining the quality of the consent rests upon each individual who initiates, directs or engages in the experiment. It is a personal duty and responsibility which may not be delegated to another with impunity.

2. The experiment should be such as to yield fruitful results for the good of society, unprocurable by other methods or means of study, and not random and unnecessary in nature.

3. The experiment should be so designed and based on the results of animal experimentation and a knowledge of the natural history of the disease or other problem under study that the anticipated results will justify the performance of the experiment.

4. The experiment should be so conducted as to avoid all unnecessary physical and mental suffering and injury.

5. No experiment should be conducted where there is an a priori reason to believe that death or disabling injury will occur; except, perhaps, in those experiments where the experimental physicians also serve as subjects. 
states that " $[\mathrm{t}]$ he voluntary consent of the human subject is absolutely essential."30 Moreover, the Code's core is that testing on human subjects can only be done if test participants give voluntary and informed consent. $^{31}$ In other words, human subjects cannot be coerced into participating in experiments or be kept ignorant of the risks to which they will be exposed.

\section{B. Declaration of Helsinki: Tempering the Nuremberg Code}

The World Medical Association (WMA) describes itself as an "apolitical" organization that "has (and indeed seeks to have) no actual powers, yet the Declarations and Statements it has made over the years have carried great weight in national and international debates."32 Indeed, the WMA's Declaration of Helsinki (the "Declaration") "has been described as "the fundamental document in the field of ethics in biomedical research." 33 In the years following the Code's issuance, many medical researchers complained that its absolutist stance on informed consent was archaic and "a product of and reaction to Nazi terror . . . no longer useful for todays's researchers." 34

6. The degree of risk to be taken should never exceed that determined by the humanitarian importance of the problem to be solved by the experiment.

7. Proper preparations should be made and adequate facilities provided to protect the experimental subject against even remote possibilities of injury, disability, or death.

8. The experiment should be conducted only by scientifically qualified persons. The highest degree of skill and care should be required through all stages of the experiment of those who conduct or engage in the experiment.

9. During the course of the experiment the human subject should be at liberty to bring the experiment to an end if he has reached the physical or mental state where continuation of the experiment seems to him to be impossible.

10. During the course of the experiment the scientist in charge must be prepared to terminate the experiment at any stage, if he has probable cause to believe, in the exercise of the good faith, superior skill and careful judgment required of him that a continuation of the experiment is likely to result in injury, disability, or death to the experimental subject.

Horst H. Freyhofer, The Nuremberg Medical Trial: The Holocaust and the Origin of the Nuremberg Medical Code 103-04 (2004) (quoting the Code).

30. Id. at 103 .

31. See id. at $103-04$.

32. World Med. Ass'n, Policy: Introduction and History, http://www.wma.net/e/policy/index. htm (last visited Feb. 12, 2008). The WMA is often confused with the World Health Organization (WHO).

33. Lori A. Alvino, Note, Who's Watching the Watchdogs? Responding to the Erosion of Research Ethics by Enforcing Promises, 103 Colum. L. Rev. 893, 896 (2003) (quoting Interna. tional Ethical Guidelines for Biomedical Research Involving Human Subjects 9 (1993)).

34. William DuBois, Note, New Drug Research, The Extraterritorial Application of FDA Regulations, and the Need for International Cooperation, 36 VAND. J. TRANSNAT'L L. 161, 203 (2003) 
Further, the Code only focused on nontherapeutic research and did not focus on the broad field of therapeutic research, where there is some promise of benefit to the subjects-such as an experimental cancer drug shown to be effective in animals that is later taken by a person with cancer.

Drafted in 1964, the Declaration "set[s] forth a list of duties and responsibilities that are expected of all physicians taking part in experimental research on humans." 35 Implicitly recognizing the Code as the signature text on bioethics, the Declaration addresses researchers' criticisms by not requiring consent for therapeutic research "where the researcher believes that it is unnecessary or difficult to obtain" and allowing for proxy consent, such as through a legal guardian or a community leader. ${ }^{36}$ However, with the exception of the consent requirements, the Declaration generally follows the contours set forth by the Code, and its stated purpose is to have medical researchers "put their patients' interest first." 37

\section{The Belmont Report: Awakening to American Abuses}

The publicized horrors of Nazi experiments on persons with no agency led to a profound rethinking about scientific research on human subjects. Since World War II, almost no country has sanctioned the use of prisoners in clinical trials with one major exception: the United States. ${ }^{38}$ The United States has a long history of conducting clinical trials on prisoners that preceded, and continued long after, the Nuremberg Trials. In fact, during the Nuremberg Trials, defense attorneys futilely argued that the Nazi physicians' actions were tantamount to "the wartime experiments in the United States such as those carried out at the Joliet, Illinois[ ] prison in which treatments for malaria were sought by physicians who had to first infect the volun-

(quoting Richard W. Garnett, Why Informed Consent? Human Experimentation and the Ethics of Autonomy, 36 CATH. Law. 455, 471-72 (1996)).

35. David M. Carr, Note, Pfizer's Epidemic: A Need for International Regulation of Human Experimentation in Developing Countries, 35 CASE W. REs. J. INT'L L. 15, 22 (2003).

36. Finnuala Kelleher, Note, The Pharmaceutical Industry's Responsibility for Protecting Human Subjects of Clinical Trials in Developing Nations, 38 Colum. J.L. \& Soc. Probs. 67, 74 (2004).

37. World Med. Ass'n, supra note 32.

38. Members of the dissident Chinese group Falun Gong have repeatedly alleged that the Chinese government has performed organ harvesting procedures on some of their imprisoned members. The Chinese government denies these allegations but has a less than stellar human rights record. See China Harvesting Falun Gong Organs, Report Alleges, CBC News, July 6, 2006, available at http:/www.cbc.ca/canada/story/2006/07/06/china-falungong.html. 
teer prisoners with the disease." 39 The U.S. military also experimented on prisoners for research involving dengue fever, sleeping sickness, and sand-fly fever. ${ }^{40}$ Further, the U.S. military and the Central Intelligence Agency have a long history of testing psychoactive drugs on enlisted soldiers without informing them that they were being used as guinea pigs. ${ }^{41}$ Following World War II, it was the pharmaceutical industry, rather than the military, that conducted most of the clinical trials involving prisoners. In fact, by $1969,85 \%$ of new drugs were tested on prisoners in over forty prison research facilities across the United States. ${ }^{42}$

Perhaps the most infamous breach of medical ethics in the United States is the Tuskegee Syphilis Study, notorious for its audacity, scope, and persistence into the post-Civil Rights Era. ${ }^{43}$ This study was conducted between 1932 and 1972 on hundreds of impoverished African American men, who were promised free medical care for participating in the trial. ${ }^{44}$ After penicillin was proven to be an effective treatment for syphilis in 1947, the researchers had no justifiable reason to continue the trial. ${ }^{45}$ However, the Tuskegee researchers received federal approval to amend and continue their study by willfully denying treatment to their subjects so that they could observe the natural course of untreated syphilis. ${ }^{46}$

39. Hoffman, supra note 20 , at 483 (emphasis and internal quotation marks omitted). This argument failed as the prosecution pressed that the Nazi victims had no choice whether to participate in the experiments, "and in the United States prisoners volunteered to participate in clinical trials." Id. Clearly the circumstances facing Nazi concentration camp prisoners and U.S. prisoners during World War II are incomparable, but one can certainly question whether U.S. prisoners had adequate agency to genuinely volunteer for the trials.

40. Id. at 482 .

41. Id. at 485-86; see also Stanley v. CIA, 639 F.2d 1146, 1148-53 (5th Cir. Unit B Mar. 1981) (holding that sovereign immunity barred a serviceman's claim that U.S. officials repeatedly gave him LSD without his knowledge when he volunteered for a military chemical warfare testing program). Several terrorism suspects that were held in Guantanamo Bay have alleged that U.S. military personnel performed medical experiments on them, perhaps demonstrating that the lessons of the Nuremberg Medical Trials have been forgotten. See, e.g., Laure Bretton, Frenchmen Say Guantanamo Detention Was Like Hell, Reuters, July 30, 2004, available at http://www.commondreams.org/headlines04/0730-07.htm.

42. Hoffman, supra note 20 , at 486 .

43. See Howard Wolinsky, Steps Still Being Taken To Undo Damage of "America's Nuremberg," 127 Annals Internal Med. I-43 (Aug. 15, 1997) (citing Arthur Caplan, When Medicine Went Mad: Bioethics and the Holocaust (1992)). The Civil Rights Era is generally recognized as occurring from the mid-1950s to mid-1960s. See JuAN WiLliams, EYES ON the Prize: America's Civil Rights Years 1954-1965 (1987).

44. See Wolinsky, supra note 43 , at I-43 to I-44.

45. Id. at I-43.

46. See id. Even the flimsy rationale of scientific curiosity is hard to accept as a justification because the natural course of syphilis is well known. Frederic Nietzche, Vincent Van Gogh, and Abraham Lincoln have famously been alleged to have suffered from the end stages of syphilis. 
During the latter half of the twentieth century, other medical trials stood out for their brazen disregard of the human subjects involved. In the 1960s, researchers at Willowbrook State Hospital, a facility for "mentally defective children," studied hepatitis by deliberately infecting children who were mentally retarded. ${ }^{47}$ The children were either fed extracts of stool from infected children or directly injected with the virus. ${ }^{48}$ While this study was ongoing, Willowbrook stopped accepting new residents due to overcrowding. ${ }^{49}$ However, because the hepatitis program was granted its own space in the facility, it still had capacity to admit new patients. ${ }^{50}$ Therefore, in some instances, the hospital would not admit children unless their parents consented to their children's participation in the study. ${ }^{51}$ In another notorious experiment in the 1960s, researchers at the Brooklyn Jewish Chronic Disease Hospital injected live cancer cells into "indigent, chronically ill, and debilitated elderly patients" to observe their immunological responses. ${ }^{52}$

Taken as a whole, these trials all share certain characteristics. First, the experimental subjects or their guardians were never properly informed of the experiments' risks. Second, the research did not promise any therapeutic benefit to the subjects. Third, and most telling, medical researchers were aware that the subjects lacked the same agency as fully empowered American adults because of the subjects' social and physical status. Therefore, these subjects could be exploited for the sake of scientific progress with little worry that they had enough power to hold the researchers accountable for practices to which the researchers themselves undoubtedly would not consent. ${ }^{53}$

See Laura McGough, Review of Pox: Genius, Madness, and the Mysteries of Syphilis, 78 BuLL. Hist. Med. 493 (2004) (book review).

47. Carl H. Coleman et al., The Ethics and Regulation of Research with Human SuBJECTS 39 (2005). Experimentation on mentally challenged children has a long and troubling history in the United States. During the 1940s and 1950s, the Massachusetts Institute of Technology and Quaker Oats fed radioactive iron to boys classified as "mentally retarded" to measure the effect of a cereal-heavy diet on mineral absorption. MIT, Quaker Oats to Settle Radiation Experiment Suit, CNN, Dec. 31, 1997, http://www.cnn.com/US/9712/31/radioactive.oatmeal/. The boys, aged twelve to seventeen, were duped into thinking they were joining a "science club." Id. In addition to radioactive materials, "club members" were treated with extra portions of milk and trips to baseball games and the beach. $I d$. Parents of the boys were not told that the study involved radioactive materials or that there would be any risks. Id. In 1997, MIT and Quaker Oats agreed to pay victims of this experiment $\$ 1.85$ million. Id.

48. Coleman et al., supra note 47 , at 39.

49. Id. at 40 .

50. Id.

51. $I d$.

52. Id. at 39 .

53. Provision five of the Code states that certain risky experiments are allowable if the researchers would subject themselves to the same risks as the subjects. FREYHOFER, supra note 29, 
Public outrage over the Tuskegee trial, coupled with the general social tumult of the early 1970 s, forced Congress to take a stronger role in overseeing human clinical trials in the United States. ${ }^{54}$ In 1974, Congress passed the National Research Act. ${ }^{55}$ Pursuant to this act, the National Commission for the Protection of Human Subjects in Biomedical and Behavioral Research (the "Commission") was established. ${ }^{56}$ Increased scrutiny of prison testing facilities revealed evidence of coercion, lack of informed consent, and unreported adverse health outcomes. ${ }^{57}$ As a consequence, in 1976, the Commission recommended a federal "moratorium on funding and approving prisoner studies" until research criteria that protected the prisoners' interests could be drafted. ${ }^{58}$ In 1979 , building upon the Code and the Declaration, the Commission issued the Belmont Report as the U.S. government's official policy statement regarding research on human subjects. ${ }^{59}$

The core principles of the Belmont Report are respect for persons, beneficence, and justice. ${ }^{60}$ The respect for persons principle reinforces the concept of informed consent and requires that "subjects enter into research voluntarily and with adequate information."61 This principle applies special scrutiny to experiments on those with

at 104. This type of provision is not reproduced in the Belmont Report or the Declaration, but clearly demonstrates that the Code authors were concerned with the different strata of power usually occupied by researchers and subjects and that perhaps one check on abuse of this power differential is a requirement that researchers be willing to subject themselves to the same risk as their subjects.

54. Hoffman, supra note 20 , at 488 .

55. Id.; National Research Act, Pub. L. 93-348, 88 Stat. 342 (codified as amended in scattered sections of 42 U.S.C.).

56. Hoffman, supra note 20 , at 488 .

57. See id. at $488-90$.

58. Id. at 488. The Commission's recommendations included Institutional Review Boards (IRBs) for prison experiments. $I d$. at 489 . The use of inmates raised concerns not present when research subjects came from the general public. See id. For instance, an IRB would institute safeguards "to ensure that the advantages that the prisoners enjoy[ed] through participation in the trial with respect to living conditions, healthcare, food, amenities, and potential earnings [were] not so great to render the inmate unable to weigh the risks of the study against its benefits in the prison environment." $I d$. Further, the risks from the trial had to be equivalent to those acceptable to nonincarcerated research subjects, and participation in research trials could not be considered when making parole decisions. Id. at 490 .

59. See Belmont Report: Ethical Principles and Guidelines for the Protection of Human Subjects of Research, Report Of the National Commission for the Protection of Human Subjects of Biomedical and Behavioral Research, 44 Fed. Reg. 23,192 (Apr. 18, 1979). See also Alvino, supra note 33, at 895-96 ("The federal regulations that currently govern federally funded research involving human subjects have their origins in two international codes: the Nuremberg Code and the Declaration of Helsinki.").

60. Belmont Report, 44 Fed. Reg. at 23,192-93.

61. Id. at 23,194 . 
diminished autonomy, such as children, those with mental handicaps, and prisoners. ${ }^{62}$ The principle of beneficence requires that the potential risks to research subjects are balanced against the potential benefits to society and mandates that research studies can only proceed if the benefits outweigh the risks. ${ }^{63}$ The principle of justice requires fairness in the distribution of research benefits and burdens among different populations.64 Thus, this principle prevents one group from bearing all of the risks and receiving none of the benefits from research, while another group receives all of the benefits but bears none of the risks. ${ }^{65}$

Pursuant to the National Research Act, the Department of Health and Human Services (DHHS) instituted regulations governing human research that became known as the "Common Rule."66 The Common Rule requires that all institutions receiving federal funds for research using human subjects must establish Institutional Review Boards (IRBs) to oversee all human research and ensure compliance with DHHS regulations. ${ }^{67}$ Thus, primarily IRBs implement the principles of the Belmont Report.

\section{Applicability of Ethical Guidelines to Globalized Trials}

There are a variety of international ethical guidelines that purport to regulate foreign drug trials. These include regulations from the Food and Drug Administration (FDA), the EU, and the World Health Organization (WHO). The texts of these guidelines have few faults. However, in practice, they are spottily enforced and fail to provide adequate protection to vulnerable research populations in developing countries.

\section{FDA Regulations and the Declaration of Helsinki}

The globalization of clinical trials truly went into effect after a 1980 FDA ruling that allowed data from foreign trials to be used in new drug applications (NDAs). ${ }^{68}$ The FDA intended for the rule change to reduce duplicative trials and shorten the time required to bring new

62. Id. at 23,193 .

63. Id. at 23,194

64. Id.

65. The justice principle is clearly being violated in many of the drug trials taking place in developing nations, as the groups bearing all of the risks are not the intended market for the drug makers and likely cannot afford new drugs with patent protection.

66. Coleman ET AL., supra note 47 , at 106.

67. Id. at 106-07.

68. See Mary Flaherty et al., Testing Tidal Wave Hits Overseas, WASH. Post, Dec. 18, 2000, at A1 (article two of the Body Hunters series). 
drugs to the market. ${ }^{69}$ However, because the FDA is charged with ensuring that new drugs are both safe and efficacious, it still has the responsibility to validate data submitted by foreign trials. ${ }^{70}$ Thus, for foreign data submitted in NDAs, the FDA requires disclosure or access to the clinical investigators, research facilities, study protocols, and individual patient records. ${ }^{71}$

One could argue that the FDA's effort to ensure the scientific integrity of clinical trial data bears little relation to the "safety of human test subjects." 72 Given the FDA's mandate to ensure the safety and efficacy of drugs, it does not appear to have an administrative rationale for protecting the rights of foreign test subjects. For instance, the safety of U.S. consumers would not be implicated if there were a lack of consent among foreign test subjects, so long as the data demonstrating safety were valid. Similarly, the efficacy of a drug would not be implicated under the scenario described above. However, by statute, the FDA purports to enforce ethical standards for clinical data used to support an NDA. ${ }^{73}$

There are two different pathways for studies to be accepted under FDA guidelines. On the one hand, a drug company can file an Investigational New Drug Application (INDA), which has the effect of "bringing the investigator, regardless of the location of the research, under the federal [research] regulations." 74 On the other hand, if a drug company chooses not to take the INDA pathway, thus avoiding direct FDA regulation, the studies used to support an NDA must still satisfy either the Declaration's guidelines or the regulations of the country where the research was conducted, "whichever represents the greater protection of the individual." 75 The FDA regulations make further demands:

69. See Julie C. Relihan, Note, Expediting FDA Approval of AIDS Drugs: An International Approach, 13 B.U. INT'L L.J. 229, 251 (1995):

In 1984, the FDA revised its policy regarding the use of foreign clinical data in response to pressure from private industry groups, foreign governments, and rising scientific standards. The FDA recognized that the unnecessary repetition of clinical studies might contribute to the length of its approval process, and that foreign clinical studies Id. had begun to produce higher quality clinical data.

70. See DuBois, supra note 34 , at $193-94$.

71. 21 C.F.R. \$ 312.120(b) (2007).

72. DuBois, supra note 34 , at 194.

73. See id. at 193-94.

74. Erin Talati, Comment, An Open Door to Ending Exploitation: Accountability for Violations of Informed Consent Under the Alien Tort Statute, 155 U. PA. L. REv. 231, 240 (2006) (emphasis omitted).

75. 21 C.F.R. $\S 312.120$ (c)(1). 
For each foreign clinical study submitted under this section, the sponsor shall explain how the research conformed to the ethical principles contained in the "Declaration of Helsinki" or the foreign country's standards, whichever were used. If the foreign country's standards were used, the sponsor shall explain in detail how those standards differ from the "Declaration of Helsinki" and how they offer greater protection. ${ }^{76}$

At least in theory, under this FDA regulation, there should not be a race to the bottom problem as an underdeveloped country's lax standards would automatically be upgraded to the Declaration's standards.

\section{Umbrella of International Ethical Guidelines}

The majority of EU countries have adopted the European Convention on Human Rights and Biomedicine (CHRB), which imposes legally binding rules on those countries that have enacted it. ${ }^{77}$ Article 5 of the CHRB provides the following regarding informed consent: "An intervention in the health field may only be carried out after the person concerned has given free and informed consent to it. This person shall beforehand be given appropriate information as to the purpose and nature of the intervention as well as on its consequences and risks."78 More specifically, Article 16 provides that clinical human research can only take place if "the persons undergoing research have been informed of their rights and the safeguards prescribed by law for their protection ... [and] the necessary consent as provided for under article 5 has been given expressly, specifically and is documented."79 Furthermore, "[s]uch consent may be freely withdrawn at any time." 80 Not surprisingly, these specific CHRB provisions mirror the Declaration's requirements.

In 1989, serious plans for the creation of a global pharmaceutical regulator began to develop at the WHO Conference of Drug Regulatory Authorities. ${ }^{81}$ The following year, the International Conference on Harmonisation of Technical Requirements for Registration of Pharmaceuticals for Human Use (ICH) was born. ${ }^{82}$ The ICH is a collaborative effort between representatives of regulatory bodies and the

\footnotetext{
76. $\S 312.120(c)(2)$.

77. Talati, supra note 74 , at 265 .

78. Council of Europe: Convention on Human Rights and Biomedicine and Explanatory Report ch. II, art. 5, Apr. 4, 1997, 36 I.L.M. 817, 821 [hereinafter CHRB].

79. CHRB, ch. V, art. 16, 36 I.L.M. $817,822$.

80. Id.

81. ICH, http://www.ich.org/cache/compo/276-254-1.html (follow "History and Future Hyperlink") (last visited Feb. 12, 2008).

82. Id. This conception is described as follows:
} 
drug industry to develop common protocols and regulations for ensuring the safety, efficacy, and testing of drugs. ${ }^{83}$ Initially, the ICH consisted primarily of representatives from the United States, Western Europe, and Japan, but it now includes observers from the WHO, which provides linkage with other regions of the globe. ${ }^{84}$ The ICH has established ethical guidelines constituting good clinical practices in the conduct of clinical human research that meet the FDA's foreign trial requirement by at least meeting the Declaration's standards. ${ }^{85}$

The Council for International Organizations of Medical Sciences (CIOMS) is a long-standing nongovernmental organization (NGO) created under the auspices of the WHO. ${ }^{86}$ Since the 1970s, one of the CIOMS's missions has been to "indicate how the ethical principles that should guide the conduct of biomedical research involving human subjects, as set forth in the Declaration of Helsinki, could be effectively applied, particularly in developing countries, given their socioeconomic circumstances, laws and regulations, and executive and administrative arrangements." 87 Recent CIOMS ethical guidelines, directed particularly at clinical trials "carried out in low resource countries," call for the standards outlined in the Belmont Report: respect for persons, beneficence, and justice. ${ }^{88}$

Harmonisation of regulatory requirements was pioneered by the European Community, in the 1980 s, as the EC (now the European Union) moved towards the development of a single market for pharmaceuticals. The success achieved in Europe demonstrated that harmonisation was feasible. At the same time there were bilateral discussions between Europe, Japan and the US on possibilities for harmonisation. It was, however, at the WHO Conference of Drug Regulatory Authorities (ICDRA), in Paris, in 1989, that specific plans for action began to materialise. Soon afterwards, the authorities approached IFPMA to discuss a joint regulatory-industry initiative on international harmonisation, and $\mathrm{ICH}$ was conceived.

The birth of $\mathrm{ICH}$ took place at a meeting in April 1990, hosted by the EFPIA in Brussels. Representatives of the regulatory agencies and industry associations of Europe, Japan and the USA met, primarily, to plan an International Conference but the Id. meeting also discussed the wider implications and terms of reference of $\mathrm{ICH}$.

83. Id.

84. Id.

85. For instance, the ICH provides the following guidelines for informed consent:

[Informed consent is a] process by which a subject voluntarily confirms his or her willingness to participate in a particular trial, after having been informed of all aspects of the trial that are relevant to the subject's decision to participate. Informed consent is documented by means of a written, signed and dated informed consent form.

ich Harmonised Tripartite Guideline: Guideline for Good Clinical Practice E6(R1) (June 10, 1996), available at http://www.ich.org/LOB/media/MEDIA482.pdf.

86. CIOMS, InTERnational ETHiCAl Guidelines for Biomedical Research Involving Human SUBJECTS (2002), available at http://www.cioms.ch/frame_guidelines_nov_2002.htm.

87. Id.

88. Id. 
3. International Ethical Guidelines without an "International" Effect

Taken as a whole, the FDA, CHRB, ICH, and CIOMS regulations demand ethical practices that are at least as robust as the Declaration's standards, no matter where a clinical trial takes place. The question then becomes whether this host of ethical regulations and guidelines actually causes researchers to meet ethical standards in foreign clinical trials. The empirical evidence is discouraging. A recent study that focused on compliance with the "best current" therapeutic efforts standard of the Declaration in sub-Saharan African clinical trials found that only $16 \%$ of studies satisfied the requirement. ${ }^{89}$ As a practical matter, in the event that the FDA does conduct any oversight of foreign testing, the oversight usually occurs after the trials are complete $;^{90}$ thus, there is no observation of the methods that were used to protect research participants. In other words, the United States's, the EU's, and Japan's drug regulatory agencies' practice of accepting foreign trials opened the door to the vast expansion of globalized trials, but without a de facto expansion of globalized ethical protections.

\section{The Body Trade: The Globalization of Human Clinical Research}

The market forces driving pharmaceutical companies to move their human experimentation to poorer nations are clear. The traditional model was for the industry to acquire test subjects and conduct trials through academic medical institutions. However, with an explosion of experimental drugs in their pipeline, companies found this traditional model too costly and time-consuming. By moving drug trials overseas and outsourcing more of their testing to contract research organizations (CROs), the pharmaceutical industry has found a business formula that provides them easier access to test subjects, with the promise of lower costs and quicker time to market for new drugs.

\section{A. Drugs, Drugs, Everywhere, Nor Any Drop of Profit?}

Advances in biotechnology, such as gene mapping and 3D modeling of protein structures, have led to a vast increase in experimental compounds that may prove to be beneficial for a variety of diseases. ${ }^{91}$ Market valuation of pharmaceutical companies depends not only on

89. Kent, supra note 10 , at 239.

90. See DuBois, supra note 34, at 193-94.

91. See Barry Hochfelder, Speeding Up Drug Discovery with Imaging, Advanced Imaging, (Sept. 2007), available at http:/www.advancedimagingpro.com/print/Advanced-Imaging-Magazine/Speeding-Up-Drug-Discovery-with-Imaging/1 $\$ 4503$. Hochfelder provided the following example: 
existing sales of approved drugs, but also on the pipeline of experimental drugs that look promising based on preliminary tissue culture and animal testing.92 In order to extract value from this pipeline, companies must perform human clinical trials to obtain market approval from drug regulatory agencies. The initial Phase 1 studies are small and test a new drug's safety. ${ }^{93}$ The moderately larger Phase 2 trials look for evidence of effectiveness. ${ }^{94}$ Finally, the large Phase 3 trials must statistically prove effectiveness - it is only after this event that drug companies can expect to profit from their research efforts. ${ }^{95}$

According to industry estimates, in order to bring a single drug to market, a company has to enroll "more than 4,000 human subjects [who will] undergo 141 medical procedures each in more than [sixtyfive] separate trials." 96 Further, clinical investigators have to entice more than 100,000 persons to enroll in the initial screenings for such trials, "as only [a small percentage will] show up for their appointments," and of those who do show up, only a small portion will be medically eligible. ${ }^{97}$ Compounding this herculean task is the fact that American and European patients are more risk averse than previous generations and are less willing to submit to such trials. ${ }^{98}$

In 1954 and 1955, American parents volunteered their children as "Polio Pioneers" by the tens of thousands, which meant that they were "guinea pigs" for Jonas Salk's new and unproven polio vaccine. ${ }^{99}$ When the results of the massive polio trial were released in 1955, the public euphoria that ensued in the United States was similar to the response to winning World War II. ${ }^{100}$ However, when an improperly made batch of the vaccine later caused over two hundred polio infections, the previously unquestioned support for this public health effort

\footnotetext{
[R]esearchers are using 3D modeling in an effort to identify small molecules that can be used as anti-cancer agents or as antiviral inhibitors for HIV, influenza and SARS, among other diseases.

The method is called computational drug design (often called structure-based or rational design). A computer is used to model how drugs interact with their targetsId. usually proteins. It's done at the molecular level in 3D.

92. See Sonia Shah, The Body Hunters: Testing New Drugs on the World's Poorest Patients 3 (2006).

93. Id.

94. $I d$.

95. Id.

96. $I d$.

97. $I d$.

98. See SHAH, supra note 92, at 4; Flaherty et al., supra note 68.

99. Laurie Garrett, Betrayal of Trust: The Collapse of Global Public Health 329 (2000).

100. $l d$.
} 
vanished. ${ }^{101}$ Additionally, revelations in the following decades of hidden risks and unethical practices in medical researchers' experiments ${ }^{102}$ further solidified public aversion to clinical experiments in the United States. ${ }^{103}$ Indeed, among cancer patients, who arguably have the most therapeutic incentive to volunteer for clinical trials, the participation rate is less than $4 \% .{ }^{104}$ Therefore, big pharmaceutical's collective glut of experimental drugs and challenges in securing human research subjects has literally created an intense competition for bodies on a global scale. Further, because it is difficult to bring the bodies "over here," more and more clinical trials are moving "over there," to developing countries. ${ }^{105}$

The fact that the number of clinical investigators in the United States has been shrinking at a rate matched by an almost commensurate growth in investigators overseas demonstrates the globalization phenomenon. ${ }^{106}$ Huge pharmaceutical companies, such as Merck, GlaxoSmithKline, and Wyeth, have estimated that they have recently expanded their human trials outside of the United States and Western Europe by $67 \% .{ }^{107}$ Even small start-up companies without a multinational footprint can get into the globalization game by outsourcing their clinical trials to CROs that conduct the clinical trials on their behalf. ${ }^{108}$

\section{B. Severing the Umbilical Cord with Academic Institutions}

As discussed above, by the late 1960s, researchers were testing the vast majority of U.S. experimental drugs on inmates in prison research facilities across the country. ${ }^{109}$ This distribution shifted after investi-

101. Id. at 329-30.

102. For example, see the discussion on the Tuskegee Syphilis Study, supra notes $43-46$ and accompanying text.

103. SHAH, supra note 92 , at 4.

104. Id.

105. See generally SHAH, supra note 92. However, for some European pharmaceutical companies, it is not cost-prohibitive to bring test subjects to their home facilities. For instance, Swiss pharmaceutical companies have relied on recruiting subjects from the Baltic States and other European countries and flying them to test facilities located in Switzerland. See Sharon LaFraniere et al., The Dilemma: Submit or Suffer, WAsh. Post, Dec. 19, 2000, at A1 (article three of the Body Hunters series). Obviously, if you added the cost of immigration, transportation, and other barriers, this practice would not be as appealing for test subjects recruited in Africa or Asia.

106. SHAH, supra note 92 , at xi.

107. Id.

108. See Ass'n of Clinical Research Orgs., CRO Industry Getting a Thumbs Up from Wall Street, available at http://www.acrohealth.org/Keylssues.php?id=8\&page=2 (last visited Feb. 12, 2008).

109. See supra notes $38-42$ and accompanying text. 
gations revealed serious ethical violations in the prison research facilities and caused drug companies to increase their ties to academia. ${ }^{110}$ From an ethics standpoint, the benefit of the enhanced pharma-university relationship arguably is that it at least ensures that the academic institution's IRB provides a higher degree of accountability. ${ }^{111}$ However, as the size of the drug market dramatically expanded in the 1980s and 1990s, pharmaceutical companies became impatient with academic centers, and by the late 1990s the monetary flow from drug companies to academic centers had greatly receded. ${ }^{112}$ As noted in the New England Journal of Medicine in 2000, "[p]harmaceutical firms are frustrated with academic medical centers ... [because] [s]low review of industry proposals . . . delays the starting date of trials." 113

Tapping on the shoulder of academic centers, and deftly not missing a step with the drug industry, has been the modus operandi of a relatively new enterprise, the CRO. CROs offer to take a company's proposal for a drug trial and then rapidly deliver patients, investigators, and ultimately crucial data for an NDA. ${ }^{114}$ In fact, CROs have proven to be such good dance partners that this industry, which does not produce any tangible product, has become a multi-billion-dollar business with expected double-digit growth until at least the next decade. ${ }^{115}$ Further, through years of industry consolidation, large multinational pharmaceutical corporations certainly have the resources to conduct their trials in-house, without the aid of academic institutions.

In addition to the sheer number of drug trials, the pharmaceutical industry's desire for fast market approval is also driving the intense competition for testing bodies. For every day that a major blockbuster drug is delayed from entering the market, researchers estimate that there is a corresponding $\$ 1$ million loss in revenue. ${ }^{116}$ The Hatch-

110. See Hoffman, supra note 20, at 488-91 (discussing the outrage over prisoner experiments and the resulting consequences).

111. This is not to ignore literature citing the limitations of the current IRB regime to adequately protect research subjects. But this flawed regime certainly provides greater protection than what was afforded U.S. inmates prior to the Belmont Report, and to participants in many developing nations today. See generally Carl H. Coleman, Duties to Subjects in Clinical Research, 58 VAND. L. REv. 387 (2005); Jesse A. Goldner, Dealing with Conflicts of Interest in Biomedical Research: IRB Oversight as the Next Best Solution to the Abolitionist Approach, 28 J.L. Med. \& ETHics 379 (2000).

112. SHAH, supra note 92 , at 6 .

113. Id. (citing Thomas Bodenheimer, Uneasy Alliance-Clinical Investigators and the Pharmaceutical Industry, 342 NEw ENG. J. MED. 1539 (2000)).

114. Id. at 6-7.

115. See Dr. Jayashree, Clinical Research Outsourcing: Overview, Current Scenario \& Future Outlook, http://www.ibpassociation.org/IBPA_articles/Outsoursing.htm (last visited Feb. 12, 2008).

116. SHAH, supra note 92 , at 5 . 
Waxman Act mitigates economic losses from delayed market approval, but the extension is limited to five years. ${ }^{117}$ In addition, there are other market factors that drive the rush for drug approval, such as the desire to get a "first-mover advantage" in a particular drug segment or secure additional investment resources. 11

The drastic difference in regulatory standards and testing costs between developed and developing countries provides pharmaceutical companies with immense incentives to relocate clinical trials overseas. ${ }^{119}$ In essence, drug companies engage in regulatory and economic arbitrage. In coarse business terms, "the value proposition" of developing countries to pharmaceutical companies is the ability to conduct substantial amounts of research with little or no prior restraint from regulatory bodies and lower capital outlays. ${ }^{120}$ The "riskiest experiments are among the first to be sent abroad."121 The unspoken understanding is that, if the host country enforces laws the multinational company dislikes, the company could simply move its resources to a less burdensome host country.

\section{Exhuming Conrad? Pfizer's Excursion into the Heart of an Epidemic}

The tale of Pfizer's Trovan drug trial in Kano, Nigeria is troubling for several reasons. First, there was the cynical exploitation of a tragic situation-an epidemic in a failed military dictatorship. Then, there

117. The Drug Price Competition and Patent Term Restoration Act of 1984, commonly referred to as the Hatch-Waxman Act, grants drug patent holders a period of additional marketing exclusivity to compensate for development time. See Drug Price Competition and Patent Term Restoration Act of 1984, Pub. L. No. 98-417, 98 Stat. 1585 (codified as amended in scattered sections of U.S.C.). The extension is added on to the term of exclusivity granted by the initial patent. Id.

118. "First-mover advantage" has been defined as follows:

The early bird gets the worm. [Game theory] shows that being the first to enter a market or to introduce an [innovation] can be a huge advantage, not just because the first firm in can erect [barriers to entry], but also because potential rivals may be discouraged from committing the resources necessary to compete successfully. However, this advantage may sometimes be cancelled out by the benefits enjoyed by followers, such as the chance to avoid-and learn from-the mistakes made by the first mover. http://www.economist.com/research/Economics/alphabetic.cfm?LETTER=F (last visited Feb. 12, 2008).

119. Almost all large pharmaceutical companies are publicly traded and must compete for investment to continue manufacturing and developing new drugs. To the extent that a certain company's operating expenses and profit margins do not match up favorably with its competitors, it will be difficult for this company to maintain investor confidence and attract more investment dollars. Market competition thus pressures the entire industry to globalize their clinical research. See Flaherty et al., supra note 68.

120. See id.

121. DuBois, supra note 34 , at 195. 
was the casual indifference to basic ethical guidelines, including obtaining informed consent and prior IRB approval. But the most disturbing aspect occurred after the trial commenced. It was the drug company's attitude of impunity - the conceit that it would face no consequences for the harms it inflicted upon impoverished and unwitting human test subjects.

\section{Medical Crisis in Nigeria}

In 1996, a massive outbreak of bacterial meningitis swept through Western Africa. ${ }^{122}$ Kano, Nigeria, an impoverished city of two million residents, was particularly hard hit. ${ }^{123}$ Bacterial meningitis is a serious infection of the tissue lining the spinal cord and brain. ${ }^{124}$ In addition to severe motor and mental damage, untreated meningitis can cause death. ${ }^{125}$

At the time of the outbreak, Nigeria was run by a military dictatorship that had one of world's worst human rights and corruption records. ${ }^{126}$ Therefore, despite massive oil wealth, Nigeria's medical and social infrastructure was woefully poor. ${ }^{127}$ Revenues from the oil fields primarily enriched foreign oil companies and a small coterie of connected elites. ${ }^{128}$ Nigerian healthcare also suffered from severe "brain drain," as a large percentage of Nigerian-trained doctors emigrated to North America and Europe. ${ }^{129}$ A few years prior to the outbreak, the United Nations (UN) estimated that 21,000 Nigerian doctors were practicing in the United States, while there was a severe shortage of doctors in Nigeria. ${ }^{130}$ All of these factors added up to a humanitarian crisis as the Nigerian government was ill-prepared to serve the needs of its citizens. In this maelstrom, foreigners set up two medical camps on the grounds of the same hospital.131 What happened at the camps was as different as light and darkness.

122. See Kristen Farrell, Comment, Human Experimentation in Developing Countries: Improving International Practices by Identifying Vulnerable Populations and Allocating Fair Benefits, 9 J. Health Care L. \& Pol'y 136, 137 (2006).

123. See Stephens, supra note 1.

124. See World Health Org., supra note 2.

125. Id.

126. See Stephens, supra note 1.

127. See CiA, The World Factbook 2007, at 422-24 (2007).

128. See id.

129. Virginia Gidley-Kitchin, UN Tackles African Brain Drain, BBC News, Feb. 22, 2000, available at http://news.bbc.co.uk/2/hi/africa/652801.stm.

130. Id.

131. Stephens, supra note 1. 


\section{Kano: A Tale of Two Camps}

The Infectious Disease Hospital in Kano is a run-down compound of cinderblock buildings, some lacking electricity, running water, and the ability to properly dispose of human waste. ${ }^{132}$ Medecins Sans Frontieres (MSF) arrived first and began to treat the victims of the outbreak with the standard line therapy for bacterial meningitis, an intensive course of IV antibiotics. ${ }^{133}$ MSF used an inexpensive generic antibiotic, chloramphenicol, which it had in ample supply. ${ }^{134}$

Whereas MSF treated the outbreak as a humanitarian crisis demanding prompt medical treatment, Pfizer saw the outbreak as an opportunity. In Pfizer's pipeline was Trovan, a broad-spectrum antibiotic projected by financial analysts to be a $\$ 1$ billion blockbuster drug if it received market approval. ${ }^{135}$ Pfizer's problem was that it did not have enough clinical data to receive regulatory approval. ${ }^{136}$ The solution to Pfizer's problem was the Infectious Disease Hospital in Kano, which, by February 1996, was receiving 120 new patients every day, many of them children. ${ }^{137}$

After learning of the outbreak on the internet, Dr. Scott Hopkins, who then led Pfizer's Trovan development team, drew up a plan to test an oral form, rather than an IV version, of Trovan on the children in the Kano clinic. ${ }^{138}$ If the oral form of Trovan could be shown to work on children as well as IV antibiotics, it would be a tremendous "breakthrough in battling epidemics" worldwide.139 "Children could simply swallow a pill" rather than receive injections that increase the risk of blood-borne diseases, such as HIV and hepatitis. ${ }^{140}$ Further, a pill would remove the need for skilled healthcare workers to assist in administration.

132. Id.

133. Id. MSF is also known as Doctors Without Borders. MSF-USA: Doctors Without Borders, http://www.doctorswithoutborders.org (last visited Feb. 12, 2008).

134. See Stephens, supra note 1. Furthermore, chloramphenicol had been recommended by the WHO as the first-line treatment for bacterial meningitis in low-income countries. See World Health Org., supra note 2.

135. Stephens, supra note 1.

136. See id.

137. Id.

138. $I d$.

139. Id.

140. Id. Many developing nations cannot afford to dispose of syringes or IV needles after each use, so they are disinfected and reused. Improper disinfection can lead to the spread of blood-borne diseases. See Reynolds Holding \& William Carlsen, Deadly Needles: Fast Track to Global Disaster, S.F. Chron., Oct. 27, 1998, at A1, available at http://www.sfgate.com/cgi-bin/ article.cgi?f=/C/a/1998/10/27/MN52NEE.DTL. 
To take advantage of this situation, spokesperson Betsy Raymond stated that Pfizer "had to move quickly." 141 The purported reason was that "[Pfizer] would not be able to find those numbers of children with spinal meningitis in the U.S." 142 However, even if Pfizer could find scores of children in the United States with spinal meningitis, it would be inconceivable that any American parent would approve or consent to their child's enrollment in an experimental antibiotics trial given the availability of proven therapies and the risks of non-efficacious treatment.

Pfizer reported that the experimental trial won rapid approval in Nigeria after an "independent review" by Nigerian authorities and "approval [by] a Kano hospital ethics committee." 143 Regarding the Nigerian military government, Dr. Hopkins explained that it was "a desperate time for them-they were happy to have anyone come in and do just about any kind of work." 144 Thus, in the sixth week of the meningitis outbreak, a team of Pfizer researchers flew into Nigeria and set up camp in the Kano hospital. ${ }^{145}$

Tensions between MSF and Pfizer arose immediately, as Pfizer's presence disrupted MSF's triage system. MSF had arranged the patients so that the sickest slept on the few available beds and benches and the less severely sick slept on mats in outdoor tents. ${ }^{146}$ For its experimental trial, Pfizer took over two of the best maintained wards, including most of the precious bed space. ${ }^{147}$ Pfizer also siphoned most of the experienced Nigerian physicians and nurses who were treating patients with MSF by paying them double the hospital's wages. ${ }^{148}$ The Pfizer team spent less than two months in Nigeria and offered no long-term follow-up care to the test subjects. ${ }^{149}$ After the trial concluded, the data were sent to the United States and promptly submitted to the FDA. 150

This gambit initially appeared to work for Pfizer. Pfizer submitted the Kano data to regulators, and Trovan subsequently received FDA approval. ${ }^{151}$ Trovan quickly became one of Pfizer's top sellers, earn-

141. Stephens, supra note 1.

142. Id.

143. Id.

144. Id.

145. Id.

146. Id.

147. Stephens, supra note 1.

148. Id.

149. Id.

150. See id.

151. Id. 
ing over $\$ 160$ million in its first year, well on its way to its predicted $\$ 1$ billion market share. ${ }^{152}$ But, then, things started to fall apart.

\section{The Unraveling of Trovan}

In 1997, FDA inspectors discovered inconsistencies in the data submitted by Pfizer from the Kano trial. ${ }^{153}$ In response to one particular FDA request, Pfizer submitted a document, dated March 1996, that purported to be from the ethics committee of a Kano teaching hospital. ${ }^{154}$ This document stated that the hospital ethics committee reviewed and approved Pfizer's Trovan study protocol before it was implemented in Kano. ${ }^{155}$ Upon further inquiry, however, the Nigerian government discovered that the document was a forgery allegedly produced by a Nigerian doctor who was paid $\$ 20,000$ by Pfizer. ${ }^{156}$ It was a poorly conceived forgery, as such things go; the referenced ethics committee did not exist in March 1996, when the trial was supposedly approved, only coming into existence seven months later in October 1996.157 In other words, the trial never had IRB approval, and Pfizer committed fraud not only upon the people of Kano, but also upon the FDA. These details all seemed moot, at least from the FDA's mandate, after postmarketing reports of liver failure from Trovan's administration led to its severely restricted use in adults in the United States and an outright ban in Europe. ${ }^{158}$ Thus, the story of the Trovan trial in Kano was destined to die as an ephemeral conspiracy, chattered about on some internet sites, but mostly ignored or dismissed as unverifiable antiglobalization hyperbole. But, in 2000 , an investigation by the Washington Post shocked this story back to life. ${ }^{159}$

First and foremost was the issue of informed consent, or rather the lack thereof. Many of the patients and their parents claimed that they did not know that they were participating in an experimental drug trial. ${ }^{160}$ They simply arrived at the Kano hospital with the understanding that international medical relief workers were there to treat them. ${ }^{161}$ This assertion was confirmed by several Nigerian healthcare

152. Id.

153. Stephens, supra note 1.

154. Barnaby Phillips, Nigeria's Drug Trial Fears, BBC News, Mar. 14, 2001, http://news.bbc. co.uk/2/hi/africa/1220032.stm.

155. Id.

156. Joe Stephens, Pfizer Faces New Charges Over Nigerian Drug Test, WAsH. Post, June 2, 2007, at D1.

157. Phillips, supra note 154.

158. Stephens, supra note 1.

159. See supra note 1.

160. See Stephens, supra note 1.

161. See id. 
workers who actually worked for Pfizer during the trial. ${ }^{162}$ In the words of one healthcare worker, "The patients did not know if it was research or not ... [t] hey just knew they were sick." 163 Pfizer claimed that local nurses were trained to explain the drug trials to patients and families, and they asserted that informed consent was received. ${ }^{164}$ However, Pfizer was not able to produce any informed consent forms. ${ }^{165}$

Further, there was evidence that Pfizer failed to switch children who were not showing any signs of improvement with Trovan onto standard therapy. ${ }^{166}$ This breach in standard protocol allegedly led to severe brain damage or death in several children.167 Additionally, there was testimony that, in the control group, Pfizer only administered one-third of the recommended dose of the antibiotic ceftriaxone-essentially a nontherapeutic dose-in order to make any beneficial effects in the Trovan treatment group seem greater by comparison. ${ }^{168}$ Compounding all of this were the families' assertions that Pfizer never told them that they were free to refuse participation in the experimental trial and instead receive free treatment in the MSF camp. ${ }^{169}$

So why does this narrative about Kano and Pfizer matter? Isn't the obvious resolution to this tale that the Nigerian victims of this unethical trial will sue Pfizer for countless dollars? Won't this legal recourse act as a deterrent for such abuses regardless of whether a potential blockbuster drug is involved? As will be discussed in the next Part, it is not clear that the victims of Kano have any power to hold Pfizer accountable in a court of law, and other multinational drug companies besides Pfizer are certainly aware of this calculus.

162. Id.

163. Id.

164. Id.

165. Id.

166. Stephens, supra note 1.

167. Id. Given the children's ill health, one cannot say for certain whether they would have survived if promptly switched to a standard therapy-but it is still a clear ethical violation, and contravention of industry practice, to continue experimental treatment in the face of nonresponsiveness when a proven therapy is available. See $i d$.

168. See Marcia Angell, The Body Hunters, 52 N.Y. Rev. Books 23 (Oct. 6, 2005) (reviewing the movie The Constant Gardener and drawing parallels to Pfizer's Trovan trial in Kano).

169. See Samantha Evans, Note, The Globalization of Drug Testing: Enforcing Informed Consent Through the Alien Tort Claims Act, 19 TeMP. INT'L \& CoMP. L.J. 477, 480 (2005). 


\section{Using Soft Law to Play Hardball WITH THE DRUG INDUSTRY}

\section{A. The Challenge of Regulating Multinational Corporations}

Multinational companies are notoriously difficult to regulate. In a sense they are denationalized; by using multiple facilities around the globe, corporations can strategically evade state power and certain national regulatory schemes. ${ }^{170}$ Further, for pharmaceutical companies in particular, developing nations' relative lack of ethical standards enforcement means that these corporations "can operate [overseas] in a largely unregulated manner."171

From an international law perspective, the challenges are both "horizontal" and "vertical" in nature, and the legal responses can be "hard" or "soft."172 For clinical drug trials, horizontal challenges constitute problems that arise between nations trying to regulate multinational drug companies that operate across international borders. ${ }^{173}$ Vertical challenges are problems with unethical trials that nationsmore likely developing nations with limited resources-face inside their borders. ${ }^{174}$ "Hard law" is represented by rule-based systems, such as the World Trade Organization (WTO), with binding authority on member states. ${ }^{175}$ "Soft law" represents guidelines, practices, and policies generated by NGOs for voluntary self-regulation by industry or future adoption by states. ${ }^{176}$ These guidelines do not have binding legal authority, which is why they are considered soft rather than hard. ${ }^{177}$

Addressing the ethical problems associated with globalized trials, some scholars have advocated a "hard horizontal" approach, envisioning an international organization with binding authority to enforce ethical standards in clinical trials on a global basis. ${ }^{178}$ Other

170. See DuBois, supra note 34 , at $195-96$.

171. Id. at 196; accord Benjamin Mason Meier, International Protection of Persons Undergoing Medical Experimentation: Protecting the Right of Informed Consent, 20 Berkeley J. INT'L L. 513, 532 (2002) ("[The] legislative vacuum [of medical experimentation regulations in developing countries] is intentional. While governments of these nations are desperate to bring medical research to their dying populations, their nations cannot afford such research without subsidies from multinational pharmaceutical corporations.").

172. See David P. Fidler, Emerging Trends in International Law Concerning Global Infectious Disease Control, 9 Emerging Infectious Diseases 285, 285, 288 (2003).

173. Id. at 285.

174. Id.

175. Id. at 288 .

176. Id.

177. Id.

178. See, e.g., Ruqaiijah Yearby, Good Enough To Use for Research, But Not Good Enough To Benefit from the Results of that Research: Are the Clinical HIV Vaccine Trials in Africa Un- 
commentators have argued for a "hard vertical" approach with horizontal effects-that is, an expansive reading of the Alien Tort Statute (ATS) to allow U.S. courts to enforce foreign violations of ethical standards. ${ }^{179}$ These proposals have merit in that they advocate greater accountability and justice in globalized drug trials, but this Article argues that there are practical limitations to these proposals: they do not offer the ethical protection for vulnerable research populations that they promise. Instead, this Article proposes that horizontal soft-law techniques, such as increased monitoring and reporting on globalized drug trials, can be used to vertically enforce existing hardlaw drug approval regulations in lucrative markets, such as the United States and the EU, in order to deter unethical research globally.

\section{B. Is the Alien Tort Statute a Viable Means of Enforcing International Violations of Ethical Standards?}

Countries hosting drug trials naturally have jurisdiction, or vertical control, over the companies involved in such testing. ${ }^{180}$ However, as some commentators have pointed out, judicial protection for research subjects in developing countries is virtually absent. ${ }^{181}$ In response, these commentators have argued for an expansive reading of the ATS to expand the United States's ability to hear foreign tort claims arising from clinical drug trials:

One method of enforcing accountability in the globalization of drug testing is through litigation subjecting corporate abusers to enormous damages. Because legislative and judicial protection in underdeveloped and often corrupt host countries is nonexistent, U.S. courts should provide a forum to punish extraterritorial abuses of informed consent during human subject experimental research

just?, 53 DePAul L. Rev. 1127, 1150 (2004) ("Another possible solution to prevent the continued exploitation of Africans and the perversion of the Justice requirement is the creation of an international compulsory standard of ethical protections of human subjects participating in clinical trials. The standards would be drafted, implemented, and enforced by one international body.").

179. See, e.g., Evans, supra note 169 , at $478-79$.

180. See Fidler, supra note 172, at 285.

181. For example, Kelleher explained as follows:

Unfortunately, many host countries do not regulate to protect human subjects of clinical trials. This lack of legislation is often intentional; clinical trials provide treatment that the governments of these countries would never be able to afford. For example, "African nations vie to minimize regulation on the conduct of medical research. They fear that legislation, and resulting lawsuits, could have a chilling effect on beneficial research efforts." Malawi, the United Republic of Tanzania, and Zambia, for example, do not have legally binding informed consent procedures . . . .

Kelleher, supra note 36 , at 85. 
sponsored by all companies that engage in business in the United States. ${ }^{182}$

Yet, as discussed below, opening U.S. courts to hear alien tort claims of abuse by multinational drug companies does not appear to be a viable solution. ${ }^{183}$

But for the 2000 Washington Post investigation, Pfizer could have easily presumed that the ghost of Kano would not haunt them. ${ }^{184}$ As a direct result of that investigation, in 2001, the American plaintiffs' law firm of Milberg Weiss filed suit in U.S. federal court against Pfizer on behalf of Nigerian children and families that participated in the Trovan trial. ${ }^{185}$ In Abdullahi $v$. Pfizer, the plaintiffs brought an action under the ATS to recover damages for Pfizer's alleged breach of the Code, the Declaration, the International Covenant on Civil and Political Rights (ICCPR), and the "law of nations." 186

The ATS was part of the Judiciary Act of $1789^{187}$ and states the following: "The district courts shall have original jurisdiction of any civil action by an alien for a tort only, committed in violation of the law of nations or a treaty of the United States."188 The ATS was largely forgotten and rarely used until invoked by plaintiffs in 1980 in Filartiga v. Pena-Irala. ${ }^{189}$ The Filartiga suit was filed by relatives of a Paraguayan who was kidnapped and tortured to death by the defendant, a Paraguayan police official. ${ }^{190}$ This opened the door to more

182. Evans, supra note 169, at 478-79; accord Talati, supra note 74, at 234 ("[T]he ATS . . provides the most promising remedy for an individual whose right to informed consent has been violated in a clinical trial conducted in a developing country. While there are significant barriers to succeeding on any ATS claim, these barriers . . . should not preclude a plaintiff from bringing an action.").

183. In addition to failing under the Sosa test, see Sosa v. Alvarez-Machain, 542 U.S. 692 (2004), this proposal runs into other difficulties. Extraterritorial extension of U.S. regulations could run afoul of the doctrine of international comity: "International comity is a doctrine that counsels voluntary forebearance when a sovereign [that] has a legitimate claim to jurisdiction concludes that a second sovereign also has a legitimate claim to jurisdiction under principles of international law." DuBois, supra note 34, at 196 (quoting United States v. Nippon Paper Indus. Co., 109 F.3d 1, 8 (1st Cir. 1997)). Also, one could anticipate that the extraterritorial application of U.S. or European law onto other nations would be perceived as tantamount to legal imperialism, with the developed world imposing its rules on unwilling countries. Id. at 205.

184. See Stephens, supra note 1.

185. Abdullahi v. Pfizer, Inc. (Abdullahi I), No.01-Civ.-8118, 2002 U.S. Dist. LEXIS 17436, at *1-8 (S.D.N.Y. Sept. 16, 2002).

186. Alien Tort Statute, 28 U.S.C. $\S 1350$ (2000); Abdullahi I, 2002 U.S. Dist. LEXIS 17436, at $* 1$.

187. Sosa, 542 U.S. at 712.

188. 28 U.S.C. $\$ 1350$.

189. 630 F.2d 876 (2d Cir. 1980).

190. Id. at $878-79$. 
foreigners filing ATS suits in the United States. ${ }^{191}$ However, in 2004, the U.S. Supreme Court revisited the ATS in Sosa v. Alvarez-Machain and left the door open only a crack. ${ }^{192}$

In Sosa, the Court determined that the ATS "was intended only to prohibit conduct for a moderate number of new international law violations that were sufficiently 'specific, universal, and obligatory.'" 193 Further, the Court severely limited the application of the ATS by reasoning that it only provided a means of redress if the abuse complained of had been recognized as a violation of international law when the statute was enacted, stating that "[w]e are persuaded that federal courts should not recognize private claims under federal common law for violations of any international law norm with less definite content and acceptance among civilized nations than the historical paradigms familiar when $\S 1350$ was enacted." 194 The Court also held that, when applying the ATS test, a lower court must "consider the practical consequences of making that cause of action available as an avenue of relief in the federal courts." 195

In Abdullahi v. Pfizer, the court recognized that "non-consensual medical experimentation violates the law of nations and, therefore, the laws of the United States." 196 However, citing Sosa, the court explained that this judicial finding provided plaintiffs with no relief, ${ }^{197}$ as "[ $t]$ he law of nations generally does not create private causes of action to remedy its violations, but leaves to each nation the task of defining the remedies that are available for international law violations."198 Similarly, the court found that, while the ICCPR "does bind the United States as a matter of international law, the United States ratified the Covenant on the express understanding that it was not selfexecuting and so did not itself create obligations enforceable in the federal courts." 199 In other words, even if the plaintiffs proved that Pfizer violated the law of nations or the ICCPR, they would not have standing to enforce such violations under Sosa.

191. Cyril Kormos et al., U.S. Participation in International Environmental Law and Policy, 13 Geo. InT'L Envtl. L. Rev. 661, 673 (2001) ("In 1980, the Second Circuit's landmark decision Filartiga $v$. Pena-Irala applied the ATS in the context of human rights violations, and in so doing opened the door to more ATS cases.").

192. 542 U.S. 692.

193. Evans, supra note 169 , at 483 (quoting Sosa, 542 U.S. at 732).

194. Id. at 484 (emphasis in original) (quoting Sosa, 542 U.S. at 732).

195. Id. at 485.

196. Abdullahi v. Pfizer, Inc. (Abdullahi III), No. 01-Civ.-8118, 2005 U.S. Dist. LEXIS 16126, at $* 25$ (S.D.N.Y. Aug. 9, 2005).

197. Id. at *25-26 (citing Sosa, 542 U.S. at 712-14).

198. Id. at *26 (quoting Kadic v. Daradzic, 70 F.3d 232, 246 (2d Cir. 1995)).

199. Id. at *36. 
The Abdullahi court also addressed the plaintiffs' claims that violations of international law as set forth in the Code and the Declaration supported jurisdiction under the ATS. ${ }^{200}$ First addressing the Code, the court held that, because "the United States has not ratified or adopted the Nuremberg Code . . . this Court declines to find the Nuremberg Code a binding source of international law giving rise to a private cause of action under the ATS." 201 Turning to the Declaration, the court declared that "[t]he Helsinki Accord does not create a private right of action in U.S. federal courts and does not have the force of law. . . . The Declaration of Helsinki . . is a mere general statement of policy that is unlikely to give rise to obligations in any strict sense." 202 The court reasoned as follows:

[A] court is not granted a roving commission to pick and choose among declarations of public and private international organizations that have articulated a view on the matter at hand. Such declarations are almost invariably political statements-expressing the sensibilities and the asserted aspirations and demands of some countries or organizations-rather than statements of universallyrecognized legal obligations. ${ }^{203}$

Thus, the court found that the Declaration was not binding law.204

Four years of dismissals and appeals in the United States and Nigeria in the Trovan litigation ${ }^{205}$ demonstrate the irrelevancy of international law in protecting human research subjects. The plaintiffs' claims were ultimately dismissed for lack of subject matter jurisdiction and forum non conveniens. ${ }^{206}$ Regarding the forum non conveniens claim, plaintiffs argued in vain that Nigeria was not a suitable forum, as one Nigerian judge-later dismissed for accepting bribes-delayed the start of the suit against Pfizer indeterminately, and the subsequent replacement judge stated that he would not hear the case for "personal reasons." 207 If plaintiffs failed under these alleged facts in a forum non conveniens analysis, it is hard to imagine a scenario where they would succeed. Perhaps the situation would have to be a wartorn, failed state where there was no effective government. But such a scenario, where a foreign drug company enters such a volatile environment, is unlikely. Therefore, it appears that multinational drug

200. Id. at *31-35.

201. Id. at *31-32.

202. Abdullahi III, 2005 U.S. Dist. LEXIS 16126, at *33-34 (internal quotation marks omitted).

203. Id. at *34.

204. Id.

205. See id. at *2, *5-14.

206. Id. at *2.

207. Id. at *6-15,*45-53. 
corporations are unfettered by international law or the domestic legal apparatuses in developing nations, and a new strategy is needed to deter unethical abuses in human clinical trials. ${ }^{208}$

\section{Is International Enforcement of Ethical Standards Feasible?}

Several commentators have proposed that international ethical standards be established as binding hard law and then be enforced horizontally through some kind of international institution, such as the UN. ${ }^{209}$ This Article is sympathetic with the goals of such proposals; however, it does not appear that they would be viable at any time in the near future. The major barriers are the matters of sovereignty and enforcement. 210

208. In 1999, the military dictatorship that was in power during the Trovan trial was replaced by a democratically elected civilian government. See THE WORLD FACrBoOK, supra note 127, at 422-24. In 2000, the Washington Post exposé about the drug trial caused an uproar and prompted not only lawsuits, but a Nigerian government investigation into what happened at Kano. Joe Stephens, Panel Faults Pfizer in '96 Clinical Trials in Nigeria, Wash. Post, May 7 , 2006, at A1. This government report, authored in 2001, concluded that Pfizer conducted an illegal drug trial that exploited those who did not clearly know that they were participating in a drug experiment, and that the government never gave authorization for this trial. Id. However, for unidentified reasons, the government suppressed this report for over five years and made only three copies. Id. One of the authors of the report later stated that he received death threats in connection with producing this document. Id. It was only through extraordinary circumstances-an anonymous leak to the international press-that this report became public five years later in 2006. Id. As a result of the leaked report, in June 2007, Nigeria filed criminal charges against Pfizer and is seeking almost $\$ 7$ billion in a civil suit. Stephens, supra note 156. This might lead one to argue that Nigeria was the proper venue for this case all along and that a legal deterrent to the actions Pfizer allegedly committed exists. However, it is evident that but for the extraordinary leak of the 2001 report and the corresponding threat to the government's legitimacy, Nigeria would not have pursued any claim against Pfizer. In other words, because it was not likely or predictable that Pfizer would be held accountable for its actions in the Trovan trial, it does not appear that a credible deterrent to future ethical abuses in similar countries exists.

209. See, e.g., Yearby, supra note 178 , at 1150.

210. One commentator further explained the barrier of enforcement:

The concept of enforcement, of course, is subject to interpretation. It could be argued, for example, that in the absence of the power to enforce, no legal duty can exist. On the other hand, it could also be argued that the concepts of 'duty' and 'enforcement' are in fact distinct and that duties-both in moral and legal terms-can be assumed by nations even when enforcement is impractical or abstract. In either event, this Article takes the position that treaty duties-including the duty to provide the highest attainable standard of health-are enforceable by means of a number of individual and interstate complaint systems at the domestic, regional, and international levels.

Wesley A. Cann, Jr., On the Relationship Between Intellectual Property Rights and the Need of Less-Developed Countries for Access to Pharmaceuticals: Creating a Legal Duty to Supply Under a Theory of Progressive Global Constitutionalism, 25 U. PA. J. INT'L ECON. L. 755, 876-77 (2004). 
Focusing particularly on HIV drug trials in Africa, Professor Yearby counseled that the best way to protect the interests of these populations is by enforcing ethical standards through an international organization. ${ }^{211}$ Yearby persuasively reasoned that other proposed schemes to protect the interests of test populations, such as using prior agreements between African countries and foreign researchers, are problematic, because "there is no enforcement mechanism."212 Instead, Yearby made the following recommendation:

[A] possible solution ... is the creation of an international compulsory standard of ethical protections of human subjects participating in clinical trials. The standard would be drafted, implemented, and enforced by one international body. The United Nations Programme on HIV and AIDS has become the premier international organization in terms of HIV and AIDS research and would be the best place for this newly formed international regulatory body. For the organization to be effective, the standards must have penalties if they are violated, and the organization must have some ability to enforce their decisions. The organization's ability to enforce this standard will be subject to the structure of its governing document and the membership of the organization....

With the creation of this compulsory international statement of ethics and enforcement, researchers and private funders will be held accountable for their ethical violations and deterred from committing the violation again, thus protecting vulnerable populations from exploitation. ${ }^{213}$

A similar proposal hypothesizes that the UN could create a permanent Nuremberg-like tribunal to enforce international human rights. 214

Focusing on transnational corporations generally, not pharmaceutical companies in particular, another article proposes that the UN establish an international organization to deal with the special human rights problems posed by these companies. ${ }^{215}$ The benefits of a single international institution include economies of scale and predictability. 216 A lone institution could ensure that companies comply with human rights standards, whereas different nations would have redun-

211. See Yearby, supra note 178, at 1132.

212. Id. at 1149 .

213. Id. at $1150-51$.

214. See Robert F. Drinan, The Nuremberg Principles in International Law, in The Nazi Doc. tors and the Nuremberg Code: Human Rights in Human Experimentation 174, 176-78 (George J. Annas \& Michael A. Grodin eds., 1992). The problem now is "how to get these principles, which are universally accepted, implemented and enforced throughout the world." Id. at 176 .

215. See Erin Elizabeth Macek, Note, Scratching the Corporate Back: Why Corporations Have No Incentive to Define Human Rights, 11 Minn. J. Global Trade 101, 122-24 (2002).

216. Id. at 120 . 
dant regulatory bodies attempting the same function. ${ }^{217}$ Another proposal suggests that "the U.N. Educational, Scientific, and Cultural Organization (UNESCO) is well positioned to create a set of international rules governing research on humans." 218 However, this proposal recognizes that UNESCO would not be able to enforce any rules or guidelines it might formulate. ${ }^{219}$ Thus, this proposal relies on the enforcement mechanisms of nations in the developing world.

While all of the proposals above recognize the need for an international standard of ethical guidelines to address transnational actors, their shortcoming is their lack of a viable enforcement mechanism. The seemingly intractable problem is one of sovereignty: How can an international body enforce legal sanctions against a party if the offending party's home country will not enforce the decision? We need only look at the difficulty facing the International Criminal Court (ICC) to envision why these proposals might not be viable.

For many years, the UN General Assembly has debated and passed resolutions regarding the establishment of a permanent international criminal tribunal. ${ }^{220}$ Pursuant to this effort, the ICC was established under the Statute of Rome.221 This Court was heralded as a "global commitment to hold ... perpetrators of gross [human rights] violations accountable for their crimes," and indeed it has overwhelming support from most of "the world's nation states."222 However, many have doubted whether the ICC will ever be viable, as the United States has vehemently objected to ICC accountability not only for U.S. government officials and military personnel, but also for corporate officers engaged in business activities overseas. ${ }^{223}$ Commenting on the American Servicemembers' Protection Act of 2002 (ASPA), 224 then Undersecretary for Arms Control and International Security, John Bolton, ${ }^{225}$ described the Bush Administration's expansive interpretation of the ASPA:

217. See id.

218. DuBois, supra note 34, at 205.

219. Id.

220. Mark D. Kielsgard, War on the International Criminal Court, 8 N.Y. City L. Rev. 1, 1-2 (2005).

221. Id. at 2 .

222. Id. (alteration in original).

223. Id. at $16-26,47-48$.

224. American Servicemembers' Protection Act of 2002, 22 U.S.C. $\$ \$ 7421-7433$ (Supp. 2002).

225. More importantly, he was appointed U.S. Ambassador to the UN in 2005. Sidestepping Senate, Bush Sends Botton to U.N., CNN.com, Aug. 2, 2005, http://www.cnn.com/2005/POLITICS/08/01/bolton.appointment/index.html. 
This broad scope of coverage is essential to ensuring that the ICC will not become an impediment to U.S. activities around the world. We must guarantee the necessary protection to our media, delegations of public and private individuals traveling to international meetings, private individuals accompanying official personnel, contractors working along side official personnel ... people engaged in commerce and business abroad ... to name just a few categories of persons. ${ }^{226}$

As it stands, the ICC has a narrow scope of jurisdiction and "will only hear four criminal charges: genocide, crimes against humanity, war crimes, and crimes of aggression." 227 Further, the criminal court assumes jurisdiction only under extraordinary circumstances and is unwilling to encroach upon a nation's sovereignty. 228 The potency and relevancy of the ICC is further diminished by the fact that China and India refuse to recognize it. ${ }^{229}$

\section{Using Soft Law to Exploit Hard Regulations that Have International Effects}

The core of this Article's proposed strategy is as follows: if the fruits of unethical research were denied access to the U.S. and EU markets, it would have the same effect as a global prohibition. In other words, this proposal argues that there is a way to achieve the same effect desired by the proposals discussed above-global deterrence of unethical research practices-without resorting to impractical legal schemes predicated on international enforcement bodies or quasi-universal jurisdiction in U.S. courts. Rather than exclusively relying on hard-law strategies, soft-law measures can be used in conjunction with existing drug regulatory powers to manipulate access to the most economically lucrative markets: the United States, the EU, and Japan.

If the hard legal authority to effectuate this proposal already exists, why do we continue to see ethical abuses in globalized clinical trials? The problem is structural in the sense that human research subjects, especially in developing nations, are not invested with any soft or hard power to hold drug companies accountable for their actions. As discussed above, investing these groups with hard power-for example, through ready access to U.S. courts--is problematic and not likely in

226. Kielsgard, supra note 220 , at 26 .

227. Id. at 7.

228. See id. at 7-8.

229. See Indian Economy to Surpass Japan, The Fin. Express, May 28, 2007, http://www. financialexpress.com/old/latest_full_story.php?content_id=165462; Q\&A: International Criminal Court, BBC News, http://news.bbc.co.uk/2/hi/africa/3834237.stm (last visited Feb. 12, 2008). 
the foreseeable future. ${ }^{230}$ However, there should be a way to invest these persons with more soft power than currently achieved by international health organizations and other NGOs typically headquartered in London, Geneva, or Washington, D.C. With the increasing accessibility of cheap internet communication, these organizations can empower human research subjects and concerned citizens in developing nations with much of the surveillance and monitoring activities of clinical drug trials. For instance, the WHO could maintain a website where alleged ethical violations can be reported with buttons translating the pages into all of the official UN languages. This reporting could then cause WHO officials to get a reporter's sworn statement, which would lead to an investigation into the alleged ethical abuses. This surveillance strategy seeks to provide a highly sensitive method of detecting ethical abuses by minimizing both the barriers to reporting and the triggering mechanism for an investigation. Even in subSaharan Africa and impoverished parts of Asia, internet access is readily available through internet cafés, kiosks, and cell phones. ${ }^{231}$ Further, anonymizing internet technology can be used to protect reporters of violations in authoritarian or repressive regimes.

The strategy described above would require additional resources to be spent in the area of clinical drug monitoring, so it is unclear how this scheme would be paid for and if it is really worth the expense. Devolving some of the monitoring functions to those being tested and concerned NGOs would mitigate some of the expenses. Further, under the framework of the $\mathrm{ICH}$, which includes groups such as Pharmaceutical Research and Manufacturers of America (PhRMA), the industry can be pressed to partially fund such an initiative, because, to the extent the drug industry is perceived as taking the lead in selfregulation to prevent ethical abuses in clinical trials, it can use this effort to portray itself in a positive light. ${ }^{232}$ Such an initiative can improve the image of the drug industry worldwide and can mitigate the resistance that this industry faces from many social activists who believe it exploits the powerlessness of developing nation populations for the benefit of rich countries. ${ }^{233}$ Further, drug regulatory agencies

230. For a discussion of Abdullahi, see supra notes 185-204 and accompanying text.

231. See Of Internet Cafés and Power Cuts, THE ECONOMist, Feb. 9. 2008, at 75.

232. PhRMA represents the pharmaceutical and biomedical industries in the United States. See About PhRMA, http://www.phrma.org/about_phrma/ (last visited Feb. 12, 2008). It is led by Billy Tauzin, a former U.S. Congressman from Louisiana, and is widely recognized as one of the most powerful industry lobbying groups in the United States. See Jim Drinkard, Drugmakers Go Furthest to Sway Congress, USA Today, Apr. 26, 2005, at $1 \mathrm{~B}$.

233. See generally Paul Farmer, Pathologies of Power: Health, Human Rights. and the New War on the PoOr (2005); Shah, supra note 92. This characterization has most fa- 
involved with the ICH could increase NDA application fees to fund such an initiative. Because the FDA has a spotty record but an actual statutory mandate for ensuring that certain ethical standards are met in foreign drug trials, it and other drug regulatory agencies would benefit from robust monitoring and surveillance of foreign human clinical trials while they are still in progress.

The simple fact that clinical investigators know that they are being watched would tend to make them more diligent in applying ethical standards. ${ }^{234}$ Furthermore, if monitoring and subsequent investigations by the WHO or some other trusted organization turn up evidence of ethical abuses, then activists can make this information public and use it to pressure drug regulatory agencies to block market approval of experimental drugs that were tested unethically. Making such ethical allegations public after confirming their veracity would shift the burden in the court of world opinion onto the alleged violators to prove that their trials were conducted in an ethical manner. This de facto burden shifting is fair, as the drug companies conducting the trials technically should already have proof of informed consent and patient protection procedures ready for viewing if they are conducting a trial consistent with international ethical norms.

\section{E. Applying the Proposal to the Trovan Case}

Assuming that Trovan had turned out to be a $\$ 1$ billion drug that was safe and efficacious, how would this proposal affect Pfizer and the status of the drug after it received market approval? What if Pfizer's home country, the United States, applies the same logic it uses against the ICC and refuses to recognize international pressure that might hurt a significant economic actor? Would this scuttle the plan's deterrent effect? The short answer is no. If Pfizer lost market approval to sell Trovan in other ICH members, such as the EU and Japan, this would have a dramatic impact not only on overall sales of this particular drug, but also on the company's stock price.

A thorny social cost issue might arise if Trovan was the only drug that could treat certain diseases and no adequate market substitute existed after its removal. This Article will not go into the details of addressing this problem, as this will be the focus of the second part of this series. Briefly, that part proposes stripping intellectual property

mously been depicted in the John le Carré novel, The Constant Gardener, along with the corresponding motion picture. See The Constant Gardener (Focus Features 2005).

234. Sociologists describe the "Hawthorne Effect" as people changing their behavior when they know that they are being watched. See Robert H. Fletcher \& Suzanne W. Fletcher, Clinical Epidemiology: The Essentials 131 (4th ed. 2005). 
rights for the fruits of unethical drug testing under the TRIPS Agreement of the WTO. The rationale for this particular proposal is to allow generic manufacturers to step into the fray to make the beneficial drug so that society can benefit without enriching a violator of ethical norms. However, generic drugs need to be evaluated for market approval as well, so this could cause a gap in the beneficial drug's availability. The solution to this problem could be a Hatch-Waxman-like rule that would allow generic manufacturers to generate Abbreviated NDA data, while the issue of stripping intellectual property rights for Trovan was before the WTO hearing body. If the market determined that Pfizer had a weak case before the WTO, then generic manufacturers would take the calculated risk of developing a generic version of Trovan without knowing for certain that Pfizer might lose patent protection. If the market determined that Pfizer had a strong case, then they would likely not start developing a generic equivalent until they knew the WTO's decision. In addition, if the United States still upheld Trovan's patent rights domestically, generically manufactured drugs from abroad could still depress Trovan's price through graymarket imports. ${ }^{235}$

This Article acknowledges that there will likely be strong opposition in some quarters to such a proposal. Some might argue that this proposal unjustly seeks to punish past behavior, which in turn may unfairly take away profits from those who think they are investing in a company with a highly lucrative drug. However, the incentives created by this proposal are clearly ex ante, as it provides a strong deterrent during the drug development process to unethical means, as they can prove to be very costly. There is already a baseline international ethical norm, the Declaration, which offers predictability as to what standards a clinical drug trial must meet. Therefore, this proposal clearly enables and creates a strong market incentive for large institutional investors to conduct due diligence on a drug company's ethical practices around the globe so that they can safeguard their investments. This type of market pressure alone, outside of any drug regu-

235. See Sabin Russell, New Crusade To Lower AIDS Drug Costs, S.F. Chron., May 24, 1999, at A1:

One of the best examples of this new front in the battle over AIDS drugs is South Africa. where a recently enacted law would override pharmaceutical company patents and allow "gray market" imports of cheap drugs from other countries.

Prescription drug prices vary dramatically from country to country, based on deals cut by the manufacturer. The antibiotic Amoxicillin, for example, costs 50 cents a pill in Johannesburg, 4 cents in Zimbabwe. The South African law would let the country pursue the lowest cost drugs on the world market.

ld. 
latory agency action, should dramatically increase ethical compliance, even in developing countries.

Another possible objection is that this proposal runs afoul of the common law takings principle by depriving parties of valuable economic and intellectual property rights. ${ }^{236}$ Under the principle of eminent domain, if the government takes property because it is useful to the public, the property holder must be compensated for this regulatory taking. ${ }^{237}$ However, in this proposal, the government is not taking these valuable rights from the owner because they are useful to the public, but to protect human research subjects from ethical abuses. In this sense, the protection of the public from ethical abuses is a valid exercise of police power and thus not a regulatory taking. 238

\section{Conclusion}

When human clinical trials are discussed in medical or pharmaceutical trade journals, numbers and statistics take on a vital role. How large was the sample size being tested? What was the magnitude of the measured effect? Was the measured effect statistically significant? How much revenue can this drug expect to generate once it receives market approval? What will be the effect on the company's stock price? Lost in all of this focus on scientific and financial numbers is the human factor. Those numbers are abstractions of events that have real impact upon many individuals, families, and communities. The degree of abstraction, or separation from the human factor, is even greater when those being tested are largely invisible to the end users of these drugs: impoverished, faceless, and voiceless masses whose stories are not very important in richer societies. Although a larger sample size translates into more robust statistical evidence, it also translates into more human exposure to risky and unproven chemical compounds. Also abstracted are the human decisionmakers in drug corporations and institutional investment firms. Although large revenue projections for a blockbuster drug can translate into a personal windfall for clinical investigators, corporate executives, and investors, it also represents the injustice of high-priced drugs not benefiting those subjected to the risk of being test subjects.

The globalization of the pharmaceutical industry and clinical drug testing is not inherently bad. Indeed, without this process, cures for

236. See Ann K. Wooster, Annotation, What Constitutes Taking of Property Requiring Compensation Under Takings Clause of Fifth Amendment to United States Constitution-Supreme Court Cases, 10 A.L.R. Fed. 2d 231 (2006).

237. Id.

238. See id. 
seemingly intractable diseases like cancer or AIDS might not be possible in the near future. However, the real and potential benefits offered by globalization in the drug industry do not mean that we have to silently accept violations of ethical standards and the absence of accountability and justice. Nobel-laureate economist Amartya Sen has summarized her feelings as follows:

Even though I'm pro-globalization, I have to say thank God for the anti-globalization movement. They're putting important issues on the agenda. ... My attitude to globalization is that one has to recognize first of all its inevitability, secondly its importance as an intellectual, social, political force, even as an economic force, but recognize that it can be very unjust and unfair and unequal, but these are matters under our control. ${ }^{239}$

In other words, we are not powerless to control the actions of companies that test drugs on human subjects in developing nations. Nor should we accept the powerlessness of human research subjects to voice their concerns or to hold drug companies accountable for breaches of ethical standards.

NGOs and international bodies such as the WHO must be more creative in using their soft power to make sure that drug companies and drug regulatory agencies are following the laws that bind them within their own sovereign jurisdictions. Furthermore, these international organizations must enable low-power human test subjects in developing countries to exert some agency in the event of ethical

239. Interview by David Barsamian with Amartya Sen (Sept. 2001), http://www.indiatogether.org/interviews/sen.htm\#part2. Sen further opined on globalization critics generally:

What we have to look at is not a kind of wholesale denunciation of globalization, which gets us nowhere. This is like King Kanute trying to discipline the sea. Quite aside from the importance of globalization, it's inescapable. It's a question of how to make it more humane and just. That requires paying attention to the underdog. I believe that virtually all the problems in the world come from inequality of one kind or another. And what we're looking at is inequality. Globalization tends to benefit most people, but not all. Some benefit greatly and others benefit relatively little. We have to see how we can make it more equitable. That requires a great deal of attention being paid to particularly labor conditions. It requires much more activism by the labor movement. It requires more reviving of cooperative attempts, and they have been successful in some countries. Bangladesh is a good example. We need more of that. It requires revision of the financial architecture of the world, because as it emerged in the 1940s it reflected a reality which is no longer true. The Bretton Woods conference in 1944 set up the IMF, the World Bank and and [sic] GATT. The WTO was the one late addition to that, but basically it's the same architecture. In the 1940s, half of the world was colonial territory. Most people were living in colonies. Democracy in the Third World was unknown. Human rights wasn't an active issue. The prospect of rapid economic growth for any poor country, especially in Asia, was unknown. The fact that people could agitate for their rights and defend the environment and demand global equity was unknown.

Id. 
breaches. The term globalization implies that we are all connected, and, certainly in the area of clinical drug trials, citizens and corporations in developed nations directly benefit from the connection with people in developing countries who serve as test subjects. However, there needs to be more power flowing in the other direction, with test subjects able to demand treatment with respect and to credibly threaten drug companies with significant economic sanctions if their rights are violated. The difficulty in legislating binding international law and overcoming issues of consensus and sovereignty should not lead us to assume the inevitability of injustice in the drug-testing arena. Legal authority exists under current drug regulatory statutes in the most lucrative economic markets to block approval of drugs that were unethically tested. 
[Vol. 57:877

Heinonline -- 57 DePaul L. Rev. 916 2007-2008 